\title{
Studies on strain sensitivity of Trichomonas vaginalis to metronidazole
}

\author{
J. G. MEINGASSNER, LISElotTE HAVELEC, AND H. MIETH \\ From Sandoz Forschungsinstitut and Institut für Medizinische Statistik und Dokumentation der \\ Universität, Vienna, Austria
}

SUMMARY Ninety-four strains of Trichomonas vaginalis isolated from unselected patients in Vienna during the period from November 1974 to November 1975 were subjected to sensitivity tests against metronidazole in vitro and in vivo. Nearly $90 \%$ of the isolates examined showed in vitro growth inhibition at concentrations of 0.4 to $1.6 \mu \mathrm{g}$ metronidazole $/ \mathrm{ml}$ and only about $10 \%$ at concentrations of less than $0.4 \mu \mathrm{g} / \mathrm{ml}$. All isolates showed some inhibition of growth after incubation for 48 hours with $3 \cdot 2 \mu \mathrm{g}$ metronidazole $/ \mathrm{ml}$. Tests on treatment carried out on experimentally infected mice revealed that all strains of $T$. vaginalis examined were sensitive to metronidazole (MDE: $<3 \times 35$ $\mathrm{mg} / \mathrm{kg}$ peroral).

\section{Introduction}

Reports on treatment failures with metronidazole (Robinson, 1962; de Carneri et al., 1963; Arnold, 1966; de Carneri, 1966; Diddle, 1967; Aure and Gjønnaess, 1969; Kurnatowska, 1969; Giannone, 1972) have been the subject of much discussion and a possible drug resistance of $T$. vaginalis has been questionied (Jennison et al., 1961; Kane et al., 1961; Squires and McFadzean, 1962; Nicol et al., 1966b; McFadzean et al., 1969; Keighley, 1971; Korner and Jensen, 1976). These observations vary primarily because of divergent findings on the susceptibility of isolates from so-called 'therapeutical non-starters' to metronidazole as demonstrated by Jennison et al. (1961), Robinson (1962), de Carneri et al. (1963), Nicol et al. (1966b), Kurnatowska (1969), and McFadzean et al. (1969).

However, experimental studies have revealed that trichomonad strains whose resistance to metronidazole was proved by tests on treatment in laboratory animals, hardly differed from sensitive reference strains when they were tested for in vitro sensitivity (de Carneri et al., 1969; Benazet and Guillaume, 1971). Thus, the value of such sensitivity tests appears to be in doubt (de Carneri et al., 1969). A possible explanation for these observations has recently been found in our investigations (Meingassner and Lindmark, 1977): it was shown that a strain of Tritrichomonas foetus $\left(\mathrm{KV}_{1} / \mathrm{M} 100\right)$, the causative agent of urogenital trichomoniasis in cattle, developed resistance to metronidazole (Meingassner and Mieth, 1976) in mice after several syringe passages under increasing drug concentrations. However, as with strains of $T$. vaginalis showing in vivo resistance to metronidazole, this strain exhibited the same sensitivity to metronidazole in vitro as the sensitive parent strain when examined under anaerobic test conditions. Under aerobic test conditions the $\mathrm{KV}_{1} / \mathrm{M} 100$ strain also proved to be highly resistant to metronidazole.

In response to these findings we have tested unselected isolates of $T$. vaginalis for their sensitivity to metronidazole in laboratory animals as well as under aerobic test conditions in vitro in order to ascertain the range of variation of the sensitivity of $T$. vaginalis.

\section{Material and methods}

ISOLATION AND CULTURE OF T. VAGINALIS Vaginal swabs were collected from 100 untreated patients with symptomatic trichomoniasis. The swabs were rinsed in a trichomonas medium (Oxoid, CM 161) containing antibiotics and the medium was then incubated for three days. In order to eliminate the concomitant microbial flora subpassages were made with 1000 iu of penicillin, $1000 \mu \mathrm{g}$ of streptomycin, and 10 iu of nystatin per ml medium. Eventually 94 isolates were cultivated under axenic conditions. Determination of the sensitivity was made on these cultures within 12

Address for reprints: Dr J. G. Meingassner, Sandoz Forschungsinstitut, Brunnerstrasse 59, A-1235 Wien, Austria

Received for publication 23 August 1977 
passages. All strains subjected to the sensitivity test had been isolated in Vienna during the period from November 1974 to November 1975.

EVALUATION OF THE IN VITRO SENSITIVITY The sensitivity of each isolate to metronidazole was estimated by determining the minimal inhibitory concentration (MIC) and the minimal lethal concentration (MLC) in a serial dilution test.

BROTH DILUTION TEST PROCEDURE

The cups of sterile cell-culture plates (Linbro Chemical Co. Inc., New Haven, Conn./USA, model $96 \mathrm{CV}$-TC) were filled with $1.4 \mathrm{ml}$ of the diluted overnight cultures of the isolates (final concentration about 50000 trichomonads/ml CM 161-medium) and with $0.1 \mathrm{ml}$ of metronidazole solution. The plates were then sealed with a pressure-sensitive tape (Scotch) and incubated for 48 hours at $37^{\circ} \mathrm{C}$. The evaluation of each isolate was made in one test with two replications. The concentration (using a twofold dilution schedule) ranged between 0.05 and $100 \mu \mathrm{g}$ of metronidazole $/ \mathrm{ml}$.

In order to determine the MIC and MLC the plates were examined in an inverted microscope with a $40 \times$ magnification. The growth was estimated subjectively in accordance with the system + to +++ , whereby the lowest concentration with + growth was regarded as the MIC. (Single motile trichomonads per cup were read as + and the culture density corresponding to the growth in untreated controls as +++ ). The MLC was the lowest concentration in which no motile trichomonads could be detected. The final evaluation was the result of the majority of the individual findings. A sensitive strain of $T$. vaginalis (A, isolated in 1971) was used as a control in every test.

\section{EVALUATION OF THE IN VIVO SENSITIVITY}

The chemotherapeutic sensitivity of the isolates was determined on ectopically-infected mice which were checked for the presence or absence of lesions and parasites six days postinfection after three peroral treatments.

\section{IN VIVO TESTING PROCEDURE}

Female NMRI-mice weighing 10-12 g were treated orally with metronidazole 2,18 , and 24 hours after a double infection with $1.2 \times 10^{6}$ trichomonads intraperitoneally and $4 \times 10^{5}$ trichomonads subcutaneously. For the isolates nos 1-70 dosage schemes of $3 \times 15,25$, and $35 \mathrm{mg}$ of metronidazole/ $\mathrm{kg}$ body weight were applied using six mice per concentration, while only one dose of $3 \times 25 \mathrm{mg} / \mathrm{kg}$ on 12 mice per concentration was used for isolates nos 71-94, as it had been found that all these dosage schemes were statistically equally reliable.

The animals were killed on the sixth day after infection. The criteria of antitrichomonal efficacy of metronidazole were based on the absence of macroscopically visible lesions in the subcutis (abscesses) and on the absence of motile trichomonads in 48-hour cultures of the abdominal cavity. To compare the dose responses the score system shown in Table 1 was used:

Table 1 Score system

\begin{tabular}{llll}
\hline Score & Culture density/abdomen & \multicolumn{2}{c}{ Size of abscesses/subcutis } \\
\cline { 3 - 4 } & & Description & $\begin{array}{c}\text { Approximate size } \\
(\mathrm{mm})\end{array}$ \\
& & & \\
0 & 0 & Normal & \\
1 & $(+)$ & Pinhead & $2-3$ \\
2 & + & Lentil & 4 \\
3 & ++ & Pea & $5-6$ \\
4 & +++ & Bean & $>6$ \\
\hline
\end{tabular}

As a control, infected, untreated groups were used to determine the pathogenicity of the isolates for mice, as well as treated groups infected with a reference strain $(E$, isolated in 1971) to compare the sensitivity.

Smears from abscesses were examined microscopically for motile trichomonads.

\section{STATISTICAL TREATMENT}

The total frequency distribution of the MIC and MLC of the 94 isolates was compared with that of the control strain A, estimated by means of the $\chi^{2}$ test. This test was also applied for assessing the metronidazole efficacy in vivo, compared with the reference strain $\mathrm{E}$.

\section{Results}

The in vitro metronidazole sensitivity of all isolates tested is summarised in Figs 1 and 2. Growth inhibition was achieved in nearly $90 \%$ with concentrations ranging from 0.4 to $1.6 \mu \mathrm{g}$ metronidazole/ $\mathrm{ml}$ medium, and in about $10 \%$ with concentrations of less than $0.4 \mu \mathrm{g} / \mathrm{ml}$. All isolates showed an inhibited growth in vitro after an incubation period of 48 hours with $3 \cdot 2 \mu \mathrm{g}$ of metronidazole/ml (Fig. 1). The values of the MLC showed a similar variation in metronidazole sensitivity. Concentrations ranging from 1.6 to $3.2 \mu \mathrm{g}$ were lethal in $85 \%$ of the isolates whereas lower concentrations were trichomonacidal in only $15 \%$. In a single isolate-although its MIC did not differ from those of the remaining isolatesthe lethal concentration was found to be $>3.2 \mu \mathrm{g}$ (Fig. 2). No marked differences in metronidazole 
sensitivity could be found between the isolates tested and the reference strain after 14 separate tests.

The findings of the sensitivity tests in vivo are summarised in Tables 2 and 3. The results of treatment in ectopically infected mice showed that all strains had the same degree of sensitivity to metronidazole. The total healing rate ascertained with doses of $25 \mathrm{mg}$ metronidazole $/ \mathrm{kg}$ body weight was $81.7 \%$ by the use of the pathological findings and $78.4 \%$ according to the results of reisolation. Not more than $33.3 \%$ of mice per treatment group remained infected after treatment with $3 \times 25 \mathrm{mg}$

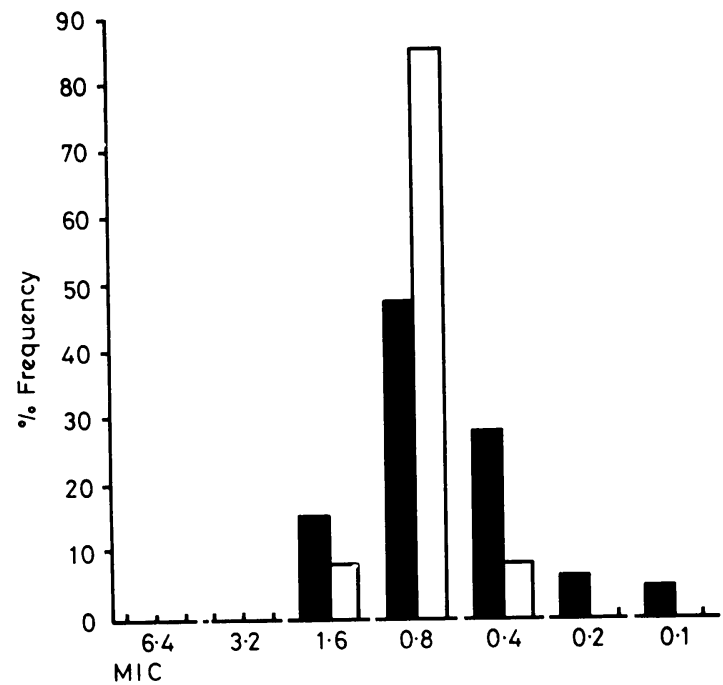

Fig. 1 In vitro activity of metronidazole against 94 isolates and a reference strain of $\mathrm{T}$. vaginalis: minimal inhibitory concentration (MIC) in $\mu \mathrm{g} / \mathrm{ml}$. metronidazole $/ \mathrm{kg}$. The result for the groups treated with dosages of $3 \times 35 \mathrm{mg} / \mathrm{kg}$ body weight was $99 \%$ (Table 2). The infected untreated controls showed that all isolates were pathogenic for mice.

The sensitivity of the isolates obtained from the ectopic infection model in vivo did not differ significantly from that of the reference strain $E$.

A comparative analysis of the efficacy of metronidazole at the two sites of infection is presented in Table 3.

In $77.6 \%$ of mice treated with $3 \times 25 \mathrm{mg}$ metronidazole/kg body weight both infection sites were cured. In $17 \cdot 7 \%$ the subcutaneous infection was

lsolates (from 94 samples)

Reference strain (from 14 tests)

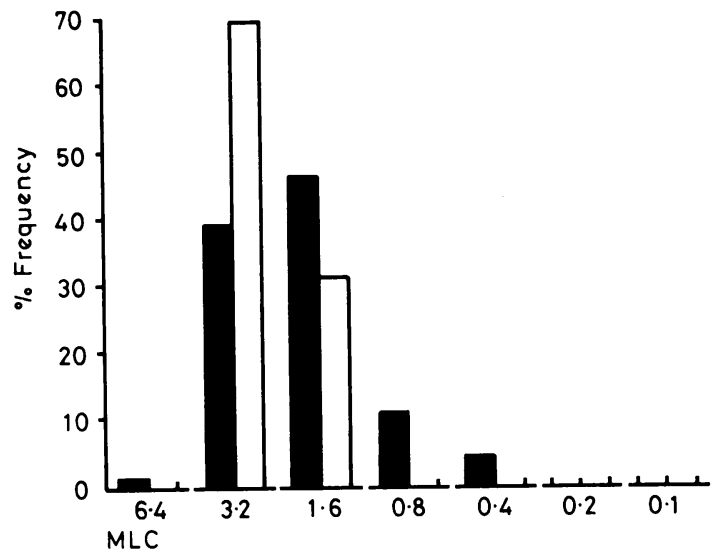

Fig. 2 In vitro activity of metronidazole against 94 isolates and a reference strain of $\mathrm{T}$. vaginalis: minimal lethal concentrations $(M L C)$ in $\mu \mathrm{g} / \mathrm{ml}$.

Table 2 Efficacy of metronidazole against 94 isolates and a reference strain of $\mathrm{T}$. vaginalis in mice: incidence of the individual findings scored with $0-4$ after peroral treatment

\begin{tabular}{|c|c|c|c|c|c|c|c|}
\hline \multirow[t]{2}{*}{$\begin{array}{l}\text { Samples of } \\
\mathrm{T} \text {. vaginalis }\end{array}$} & \multirow{2}{*}{$\begin{array}{l}\text { Dosage } \\
\text { (mk/kg body } \\
\text { weight) }\end{array}$} & \multicolumn{5}{|c|}{$\begin{array}{l}\text { Score } \\
(\% \text { incidence })\end{array}$} & \multirow[t]{2}{*}{$\begin{array}{l}\text { No. of } \\
\text { animals }\end{array}$} \\
\hline & & 0 & 1 & 2 & 3 & 4 & \\
\hline \multirow[t]{3}{*}{ Isolates } & $3 \times 15$ & $\begin{array}{l}5 \cdot 0 \\
1 \cdot 7\end{array}$ & $\begin{array}{r}69 \cdot 2 \\
3 \cdot 6\end{array}$ & $\begin{array}{l}23 \cdot 5 \\
38 \cdot 1\end{array}$ & $\begin{array}{r}2 \cdot 3 \\
54 \cdot 6\end{array}$ & $\begin{array}{l}0 \cdot 0^{*} \\
2 \cdot 0 \dagger\end{array}$ & $302 \ddagger$ \\
\hline & $3 \times 25$ & $\begin{array}{l}81 \cdot 7 \\
78 \cdot 4\end{array}$ & $\begin{array}{r}17 \cdot 8 \\
7 \cdot 1\end{array}$ & $\begin{array}{r}0 \cdot 3 \\
13 \cdot 3\end{array}$ & $\begin{array}{l}0 \cdot 2 \\
1 \cdot 3\end{array}$ & $\begin{array}{l}0 \cdot 0^{*} \\
0 \cdot 0 \dagger\end{array}$ & 870 \\
\hline & $3 \times 35$ & $\begin{array}{l}99 \cdot 1 \\
99 \cdot 4\end{array}$ & $\begin{array}{l}0 \cdot 9 \\
0 \cdot 3\end{array}$ & $\begin{array}{l}0 \cdot 0 \\
0 \cdot 3\end{array}$ & $\begin{array}{l}0.0 \\
0.0\end{array}$ & $\begin{array}{l}0.0^{*} \\
0.0 \dagger\end{array}$ & $325 \ddagger$ \\
\hline $\begin{array}{l}\text { Infected } \\
\text { controls }\end{array}$ & Untreated & $\begin{array}{l}0.0 \\
0.0\end{array}$ & $\begin{array}{r}10.5 \\
0.0\end{array}$ & $\begin{array}{r}52 \cdot 0 \\
0 \cdot 0\end{array}$ & $\begin{array}{l}37 \cdot 5 \\
51 \cdot 6\end{array}$ & $\begin{array}{r}0 \cdot 0^{*} \\
48 \cdot 4 \dagger\end{array}$ & 564 \\
\hline $\begin{array}{l}\text { Reference } \\
\text { strain E }\end{array}$ & $3 \times 25$ & $\begin{array}{l}88 \cdot 6 \\
81 \cdot 5\end{array}$ & $\begin{array}{r}11 \cdot 4 \\
3 \cdot 8\end{array}$ & $\begin{array}{r}0 \cdot 0 \\
14 \cdot 7\end{array}$ & $\begin{array}{l}0.0 \\
0.0\end{array}$ & $\begin{array}{l}0.0^{*} \\
0.0 \dagger\end{array}$ & $184 \ddagger$ \\
\hline
\end{tabular}

* Lesions in the subcutis

+ Density of trichomonads in cultures of the abdominal cavity

‡ Several groups comprised fewer than 6 or 12 animals 
Table 3 Comparison of the efficacy of metronidazole in mice according to the mode of infection: incidence of different findings after peroral treatment of subcutaneous or intraperitoneal infections

\begin{tabular}{|c|c|c|c|c|c|}
\hline \multirow[t]{2}{*}{$\begin{array}{l}\text { Samples of } \\
T \text {. vaginalis }\end{array}$} & \multirow{2}{*}{$\begin{array}{l}\text { Dosage } \\
\text { (mg/kg body } \\
\text { weight })\end{array}$} & \multicolumn{3}{|l|}{$\begin{array}{l}\text { Differences in the scoring system } \\
(\% \text { frequency) }\end{array}$} & \multirow[t]{2}{*}{$\begin{array}{l}\text { No. of } \\
\text { animals }\end{array}$} \\
\hline & & Intraperitoneal $<$ subcutaneous* & Intraperitoneal $=$ subcutaneous $\dagger$ & Intraperitoneal > subcutaneous + & \\
\hline Isolates & $\begin{array}{l}3 \times 15 \\
3 \times 25 \\
3 \times 35\end{array}$ & $\begin{array}{r}89 \\
17 \cdot 7 \\
0 \cdot 6\end{array}$ & $\begin{array}{r}9 \cdot 3 \\
77 \cdot 6 \\
98 \cdot 5\end{array}$ & $\begin{array}{l}1 \cdot 7 \\
4 \cdot 7 \\
0 \cdot 9\end{array}$ & $\begin{array}{l}302 \S \\
870 \\
325 \oint\end{array}$ \\
\hline $\begin{array}{l}\text { Reference } \\
\text { strain E }\end{array}$ & $3 \times 25$ & $18 \cdot 5$ & $80 \cdot 4$ & $1 \cdot 1$ & 1845 \\
\hline
\end{tabular}

*Clearance better in subcutaneous infections than in intraperitoneal infections †Clearance identical in subcutaneous and intraperitoneal infections

$\ddagger$ Clearance better in intreaperitoneal infections than in subcutaneous infections §Several groups comprised fewer than 6 or 12 animals

cleared and the peritoneal was not, whereas the reverse was true in only $4.7 \%$.

\section{Discussion}

In vitro sensitivity tests carried out on 94 isolates of $T$. vaginalis revealed that all specimens were sensitive to metronidazole to almost the same degree. This was also shown very clearly by the results from the experiments in mice. The MLC value of only one strain was $6.4 \mu \mathrm{g} / \mathrm{ml}$, although its growth sensitivity and susceptibility to metronidazole in vivo did not differ from the remaining isolates. The reason we employed the double-infection method was that while subcutaneous infections with strains of $T$. vaginalis of unknown virulence can more easily be established than intraperitoneal infections, intraperitoneal infections do permit a more reliable evaluation of treatment. However, in our assay all intraperitoneal infections proved to be successful. Distinct therapeutic differences owing to the mode of infection were found in the dosage group of $3 \times 15 \mathrm{mg} / \mathrm{kg}$ which, we believe, might be explained by the different modes of assessment used. The results of treatment in mice infected subcutaneously were assessed macroscopically (which may be considered a rather rough evaluation), while intraperitoneally infected mice were evaluated by reisolating trichomonads from the abdominal cavity which proved to be far more reliable.

Various workers have pointed out (Nicol et al., 1966a; McFadzean et al., 1969) that it is possible that metronidazole may be inactivated by the vaginal bacterial flora, so we used only decontaminated cultures for our studies. Those samples which could not be cultivated axenically with penicillin, streptomycin, and nystatin after 12 subpassages were therefore rejected.

Considering the fact that we conducted our studies on unselected patients suffering from vaginal discharge and it may therefore be assumed that they comprised primary cases and reinfections as well as exacerbations or uncured cases (although no amnanestic details were known), we feel that the results were remarkably uniform. In neither test system did the isolates significantly differ one from another or from the reference strains regarding their sensitivity. Resistant and 'relatively' resistant strains were not found with our assay system, nor did the strains show a gradual decrease of susceptibility compared with the reference strains as described by Giannone (1972).

We wish to thank Dr O. Palla and Dr J. Scholz for providing the test strains, Mr K. Stockinger for his technical assistance, and Dr P. F. Troke for his criticism of the manuscript.

\section{References}

Arnold, M. (1966). Beobachtungen und Probleme bei der Behandlung der Trichomonas vaginalis. Therapeutische Umschau (Bern), 23, 356-359.

Aure, J. C., and Gjønnaess, H. (1969). Metronidazole treatment of trichomonal vaginitis. Acta obstetricia et gynecologica Scandinavica, 48, 440-445.

Benazet, F., and Guillaume, L. (1971). Induction of in vivo resistance of Trichomonas vaginalis to nitrimidazine. Lancet, 2, 982-983.

de Carneri, I. (1966). Variation of the sensitivity of a strain of Trichomonas vaginalis to metronidazole after culturing in the presence or absence of the drug. In Proceedings of the First International Congress of Parasitology, Rome 1964, pp. 366-367. Edited by A. Corradetti. Pergamon Press: Oxford.

de Carneri, I., Achilli, G., Monti, G., and Trane, F. (1969). Induction of in vivo resistance of Trichomonas vaginalis to metronidazole. Lancet, 2, 1308-1309.

de Carneri, I., Baldi, G. F., Giannone, R., and Passalia, S. (1963). Osservazioni preliminari su ceppi di Trichomonas vaginalis naturalmente resistenti al metronidazolo. Archivio di obstetricia e ginecologia, 68, 422-432.

Diddle, A. W. (1967). Trichomonas vaginalis: Resistance to metronidazole. American Journal of Obstetrics and Gynecology, 98, 583-585.

Giannone, R. (1972). Rilievi sull'aumento della resistenza al metronidazolo dei ceppi di Trichomonas vaginalis in Lombardia. Minerva ginecologica, 24, 354-355.

Jennison, R. F., Stenton, P., and Watt, L. (1961). Laboratory studies with the systemic trichomonacide, metronidazole. Journal of Clinical Pathology, 14, 431-435. 
Kane, P. O., McFadzean, J. A., and Squires, S. (1961). Absorption and excretion of metronidazole. Part II. Studies on primary failures. British Journal of Venereal Diseases, 37, 276-277.

Keighley, E. E. (1971). Trichomoniasis in a closed community: Efficacy of metronidazole. British Medical Journal, 1, 207-209.

Korner, B., and Jensen, H. K. (1976). Sensitivity of Trichomonas vaginalis to metronidazole, tinidazole, and nifuratel in vitro. British Journal of Venereal Diseases, 52, 404-408.

Kurnatowska, A. (1969). Metronidazole resistance of Trichomonas vaginalis Donné. Wiadomości Parazytologiczne, 15, 399-401.

McFadzean, J. A., Pugh, I. M., Squires, S. L., and Whelan, J. P. F. (1969). Further observations on strain sensitivity of Trichomonas vaginalis to metronidazole. British Journal of Venereal Diseases, 45, 161-162.

Meingassner, J. G., and Lindmark, D. G. (1977). Assay conditions and the detection of nitroimidazole resistance in Tritrichomonas foetus. Fifth International Congress of Protozoology, New York, 1977, abstract 392. (Proceedings to be published.)
Meingassner, J. G., and Mieth, H. (1976). Cross-resistance of trichomonads to 5-Nitroimidazole-derivatives. Experientia, 32, 183-184.

Nicol, C. S., Evans, A. J., McFadzean, J. A., and Squires, S. L. (1966a). Inactivation of metronidazole. Lancet, 2, 441.

Nicol, C. S., McFadzean, J. A., and Squires, S. L. (1966b). Trichomonas vaginalis resistance. Lancet, 1, 1100-1101.

Robinson, S. C. (1962). Trichomonal vaginitis resistant to metronidazole. Canadian Medical Association Journal, 86, 665.

Squires, S., and McFadzean, J. A. (1962). Strain sensitivity of Trichomonas vaginalis to metronidazole. British Journal of Venereal Diseases, 38, 218-219. 